\title{
OVER-EXPRESSION OF GENE ENCODING FATTY ACID METABOLIC ENZYMES IN FISH
}

\author{
Alimuddin*), Goro Yoshizaki**), Toshio Takeuchi**), and Odang Carman*)
}

\begin{abstract}
Eicosapentaenoic acid (EPA, 20:5n-3) and docosahexaenoic acid (DHA, 22:6n-3) have important nutritional benefits in humans. EPA and DHA are mainly derived from fish, but the decline in the stocks of major marine capture fishes could result in these fatty acids being consumed less. Farmed fish could serve as promising sources of EPA and DHA, but they need these fatty acids in their diets. Generation of fish strains that are capable of synthesizing enough amounts of EPA/DHA from the conversion of $\alpha$ linolenic acid (LNA, 18:3n-3) rich oils can supply a new EPA/DHA source. This may be achieved by over-expression of genes encoding enzymes involved in HUFA biosynthesis. In aquaculture, the successful of this technique would open the possibility to reduce the enrichment of live food with fish oils for marine fish larvae, and to completely substitute fish oils with plant oils without reducing the quality of flesh in terms of EPA and DHA contents. Here, three genes, i.e. $\triangle 6$-desaturase-like (Om $\triangle 6 \mathrm{FAD}), \Delta 5$-desaturase-like (Om $\triangle 5 \mathrm{FAD})$ and elongase-like (MELO) encoding EPA/ DHA metabolic enzymes derived from masu salmon (Oncorhynchus masou) were individually transferred into zebrafish (Danio rerio) as a model to increase its ability for synthesizing EPA and DHA. Fatty acid analysis showed that EPA content in whole body of the second transgenic fish generation over-expressing Om $\triangle 6 F A D$ gene was 1.4 fold and that of DHA was 2.1 fold higher $(\mathrm{P}<0.05)$ than those in non-transgenic fish. The EPA content in whole body of transgenic fish over-expressing Om $\triangle 5 F A D$ gene was 1.21 -fold, and that of DHA was 1.24 -fold higher $(\mathrm{P}<0.05)$ than those in nontransgenic fish. The same patterns were obtained in transgenic fish over-expressing MELO gene. EPA content was increased by 1.30 -fold and DHA content by 1.33 -fold higher $(\mathrm{P}<0.05)$ than those in non-transgenic fish. The results of studies demonstrated that fatty acid content of fish can be enhanced by over-expressing gene encoding enzymes involved in fatty acid biosynthesis, and perhaps this could be applied to tailor farmed fish as even better sources of valuable human food.
\end{abstract}

\section{KEYWORDS: expression, gene, fatty acid, biosynthesis, fish}

\section{INTRODUCTION}

Transgenic fish has been generated in a number of freshwater fish species, such as goldfish (Zhu et al., 1985), rainbow trout (Chourrout et al., 1986), channel catfish (Dunham et al., 1987), carp (Powers et al., 1992), medaka (Takagi et al., 1994), tilapia (Martinez et al., 1996), zebrafish (Higashijima et al., 1997); marine fishes, such as seabream (Cavari et al., 1993; Garcia-Poso et al., 1998), salmonids (Devlin 1997), ice goby (Nakatsuji, 2000), and in invertebrates, such as abalone Halitotis rufescens (Powers et al., 1995), dwarf surfclam

") Department of Aquaculture, Faculty of Fisheries and Marine Science, Bogor Agricultural University. Bogor 16680

**) Department of Marine Biosciences, Tokyo University of Marine Science and Technology, Minato, Tokyo 108-8477, Japan 
Mulina lateralis (Lu et al., 1996), and crayfish Procambarus clarkii (Sarmasik et al., 2001). Most of transgenic works are focused on enhancement of growth. Due to the lack of fish gene sequences, initial transgenic research in the mid-1980s employed mammalian growth hormone $(\mathrm{GH})$ gene constructs, which enhanced growth in some, but not all examined fish species (Zhu et al., 1986; Zhu 1992; Gross et al., 1992). Subsequent gene constructs using fish $\mathrm{GH}$ sequences have stimulated some growth enhancement (less than a double of weight compared with controls) in carp, catfish, zebrafish and tilapia (Zhang et al., 1990; Dunham et al., 1992; Chen et al., 1993; Zhao et al., 1993), providing the first convincing evidence that growth enhancement in fish can be achieved by transgenesis. Transgenic fish with remarkable growth rates have been obtained by introducing a fish growth hormone gene driven by a suitable fish promoter (Devlin et al., 1994; Rahman et al., 1998; Hew \& Fletcher, 2001; Nam et al., 2001).

Recently, transgenic technology can also be used to induce or enhance adaptation to extreme environmental condition and disease resistance. Enhancement of adaptation to low temperature using ocean pout antifreeze protein (AFP) gene into goldfish has been achieved (Wang et al., 1995). The development of stocks harboring AFP gene would clearly be a major benefit in commercial aquaculture in countries where winter temperatures often border the physiological limits of these species. On the other hand, increase the resistant to bacterial pathogen has been attained by transferring cecropin gene of silk moth, Hyalophora cecropia into medaka (Sarmasik et al., 2002) and channel catfish (Dunham et al., 2002). Cecropin is a group of antimicrobial peptides with bactericidal activity against a broad spectrum of bacteria. More recently, transgenic zebrafish carrying lysozyme gene enhanced its disease resistance (Yazawa et al., 2005).

Transgenic technology has successfully been used to produce an important hormone, luteinizing hormone (Morita et al., 2004) and therapeutic proteins; human coagulation factor VII (Hwang et al., 2004), insulin (Pohajdak et al., 2004), and a-antitrypsin (Morita et al., 2005). This technology has also been applied to generate a new variety of ornamental fish by introduction of fluorescent proteins (Wan et al., 2002; Gong, 2003). This has implications for the ornamental fish industry. For generating an eco-friendly aquaculture system, transgenic technology has been tried to apply in order to reduce ammonia loading from fish into environment by over-expressing growth hormone gene (Kobayashi et al., 2007). Further, the transgenic technology has provided a model fish as sentinels for water pollution (Carvan et al., 2000). This transgenic fish is carrying green fluorescent protein gene driven by a number of promoters which will respond to water pollutants, such as heat shock proteins, metallothioneins which are induced by general stress, heavy metals or chemical toxins. This system has enabled a continual qualitative biosensors for water contamination, inexpensive assay, providing rapid and visible results (Melamed et al., 2002).

Few studies have been conducted in relation to modification of fish metabolism pathway by using transgenic technique. Toyohara et al. (1996) studied the potential of gene transfer to compensate the absence of vitamin C biosynthesis in fish. The method involved the introduction of the L-guluno-g-lactone oxidase gene that acted as a catalyst for the terminal reaction of vitamin C. However, no vitamin C production was observed. The improvement of carbohydrate metabolism in rainbow trout by co-injection of a construct containing human glucose transport proteins (hGluT1) and rat hexokinase II (rHKII) cDNAs has also been attempted. However, no direct evidence for the functionality of rHKII and hGluT1 was observed (Pitkanen et al., 1999). Furthermore, another interesting field that remains to be explored in relation to fish metabolic pathway is modification of $n-3$ highly unsaturated fatty acids (HUFA) biosynthesis pathways.

The $n-3$ HUFA, especially eicosapentaenoic acid (EPA, 20:5n-3) and docosahexaenoic acid (DHA, 22:6n-3) are important nutrients for human because they contribute to several aspects of health, including the development of infant brain, the function of eyes (Lauritzen et al., 2001), the prevention of cardiovascular and inflammation disease (Simopoulos, 2002), metabolic syndrome (Nugent, 2004), cancer (Hardman, 2004), and Alzheimer's disease (Cole et al., 2005). EPA and DHA are also essential fatty acids for marine fish. The inclusion of the two fatty acids in fish diets are known to improve the quality of broodstocks, and the growth and normal development of larvae (Watanabe, 1993; Furuita et al., 2000; Takeuchi, 2001; Copeman et al., 2002; Watanabe \& Vassallo-Agius, 2003; Mazorra et al., 2003). Moreover, HUFA have been shown to promote 
tolerance to handling stress (Koven et al., 2001), increase cellular (Wu et al., 2003), and humoral (Kiron et al., 1995) defense responses and offer disease resistance (Kiron et al., 1995). These fatty acids also enhanced the schooling behavior of the larval yellowtail (Ishizaki et al., 2001).

The main source of EPA and DHA for human consumption is marine fish. However, most marine fishes have already reached a plateau in their yield or are on the verge of collapse (Myers \& Worm, 2003). Aquaculture has potential to be an alternative source of EPA and DHA for human consumption. Additionally, it has been predicted that aquaculture will contribute more to global food fish supplies and further help reducing food insecurity over the next two decades (FAO, 2001). One of major challenges in aquaculture production is high quality food supply in the future. Lipid is the major energy source for farmed marine fish species, with up to $40 \%$ lipid in the feed (OpsahlFerstad et al., 2003). This is mainly supplied as fish oil rich in HUFA. The demand for fish oil is, however, increasing rapidly, both from aquaculture and also from other users e.g., poultry producers (Opsahl-Ferstad et al., 2003). This is expected to increase the price of this feed ingredient, and the demand will likely exceed the supply in the near future. Considering fish oil long-term availability, many research have been carried out on the use of plant as fish oil substitute. But, the inclusion of high amount of plant oils has reduced the quality of flesh in terms of EPA and DHA contents (Tocher et al., 2000; Bell et al., 2001, 2002). This is because vegetable oils are generally rich in unsaturated $\mathrm{C} 18$ fatty acids, such as $\alpha$-linolenic acid (LNA, 18:3n-3), but EPA and DHA are absent, and fish has low ability to synthesize the two fatty acids. Thus, there is a considerable demand to find a way that allows fish to use plant oils without reducing EPA/DHA production.

Many studies have demonstrated that the ability of fish to synthesize EPA and DHA from dietary LNA is dependent on a complex of desaturase and elongase enzyme activities (Buzzy et al., 1996; Tocher et al., 1998; Ghioni et al., 1999). There are two types of desaturase involved in EPA/DHA biosynthesis that can be distinguished based on their desaturation site in the fatty acids; $\Delta 6$ - and $\Delta 5$-desaturase (Sprecher, 1981; Tocher et al., 1998; Sprecher, 2000). $\Delta 6$-desaturase enzyme uses LNA as the substrate and allows the insertion of a double bond to produce octadecatetraenoic acid (OTA,
$18: 4 n-3)$. The OTA is converted by elongase to produce eicosatetraenoic acid (ETA, 20:4n-3), a substrate of $\Delta 5$-desaturation in the EPA synthesis. Furthermore, EPA is converted by sequential chain elongation processes to produce the fatty acid $22: 5 n-3$ and then to $24: 5 n$ 3 . Fatty acid $24: 5 n-3$ is metabolized by $\Delta 6$ desaturase enzyme to produce $24: 6 n-3$, which is finally retro-converted by peroxisomes via $\beta$-oxidation to yield DHA (Buzzy et al., 1996; 1997; Infante \& Huszagh, 1998; Sprecher, 2000). In addition, a simple synthesis pathway for DHA that is directly converted from $22: 5 n$ 3 by a $\Delta 4$-desaturation in marine organism has recently been described (Qiu et al., 2001; Meyer et al., 2003; Tonon et al., 2003; 2005).

Vertebrates, including fish are lacking the $\Delta 12$ - and $\Delta 15$-desaturase enzyme activities, which are required to convert oleic acid $(18: 1 n-9)$ for the production of LNA. Thus, LNA must be derived from the diet. LNA can be further desaturated and elongated to varying degrees depending on the animal species, $\Delta 6$ desatuarse, $\Delta 5$-desaturase and elongase enzyme activity, and tissue location. In general, the rate-limiting step in HUFA biosynthesis of vertebrates is $\Delta 6$-desaturation (Sprecher, 1981; Cho et al., 1999). Cats have been reported to lack or express relatively low $\Delta 6$ (and possibly $\Delta 5)$ desaturase activity (Rivers et al., 1975). Marine fishes such as gilthead sea bream and golden gray mullet have a functional $\Delta 6$ desaturase, but display limited $\Delta 5$-desaturase activity (Tocher \& Sargent, 1990; Mourente \& Tocher, 1994), while turbot displays limited elongase enzyme activity (Ghioni et al., 1999). Freshwater fishes including trout, carp, tilapia, and zebrafish have functional $\Delta 5$ - and $\Delta 6$ desaturase (Henderson, 1996; Hasting et al., 2001), and elongase enzyme activity (Agaba et al., 2004) and can produce EPA and DHA.

Recently, genes encoding EPA/DHA biosynthetic enzymes, i.e. $\Delta 6$-desaturase (Seiliez et al., 2001, 2003; Zheng et al., 2005), bi-functional $\Delta 5 / \Delta 6$-desaturase (Hasting et al., 2001), $\Delta 5$-desaturase (Hasting et al., 2004), and elongase (Hasting et al., 2004, Agaba et al., 2005) genes have been isolated from several fish species. We had also isolated genes involved in HUFA biosynthesis from masu salmon, Oncorhynchus masou. They are $\Delta 6$-desaturaselike (Om $\Delta 6 \mathrm{FAD}), \Delta 5$-desaturase-like (Om $\Delta 5 \mathrm{FAD})$ and elongase-like (MELO) genes. This opens the possibility to modify HUFA biosynthesis pathway by over-expression of these genes to increase EPA/DHA production in fish. 
Generation of fish strains that are capable of synthesizing enough amounts of EPA/DHA from the conversion of LNA rich oils can supply a new EPA/DHA source for human consumption. This may be achieved by over-expression of genes encoding enzymes involved in HUFA biosynthesis. In aquaculture, the successful of this technique would open the possibility to eliminate the enrichment of live food with fish oils for marine fish larvae, and to completely substitute fish oils with plant oils without reducing the quality of flesh in terms of EPA and DHA contents. This permits the growing aquaculture industry to depend less on ocean fisheries stocks as ingredients for aquatic diets. Furthermore, when transgenic technique is adopted for farmed fish, diet costs could substantially be kept lower since cheaper plants sources rich in LNA would be nutritionally adequate for them. Additionally, though controversial, some of the marine cultured fishes have been reported to contain higher level of toxic contaminants such as dioxin and polychlorinated biphenyls (PCBs) compared with wild fish (Jacob et al., 2002a, b; Hites et al., 2004), attributed to the inclusion of contaminated fish oil in the feeds. Substitution of fish oils with vegetable oils could reduce the accumulation levels of dioxin and
PCBs (Bell et al., 2005), but high inclusion level of plant oils in the diets reduces the EPA and DHA contents in fish (Tocher et al., 2000; Bell et al., 2001, 2002). The use of transgenic fish possessing high ability to synthesize EPA and DHA and utilize diets containing plant oils could potentially diminish the contamination of dioxin and PCBs without reducing the flesh quality in terms of EPA/DHA contents.

In this paper, we reported the improvement of EPA/DHA biosynthesis by over-expression of gene encoding fatty acid metabolic enzymes using zebrafish, Danio rerio as a model. Genes encoding EPA/DHA metabolic enzymes were isolated from masu salmon (Oncorhynchus masou). Zebrafish was used as a model organism to achieve the goal of this study because it offers several major advantages such as a relatively short life span (2-3 months), large number of eggs, and ease of maintaining (Westerfield, 1995; Gong, 1999).

\section{PRODUCTION OF TRANSGENIC FISH}

Fish were spawned and cultured as described by Westerfield (1995), with some modifications. Transgenic zebrafish carrying a foreign gene was generated by microinjecting 1cell embryos (Figure 1a), with a plasmid DNA
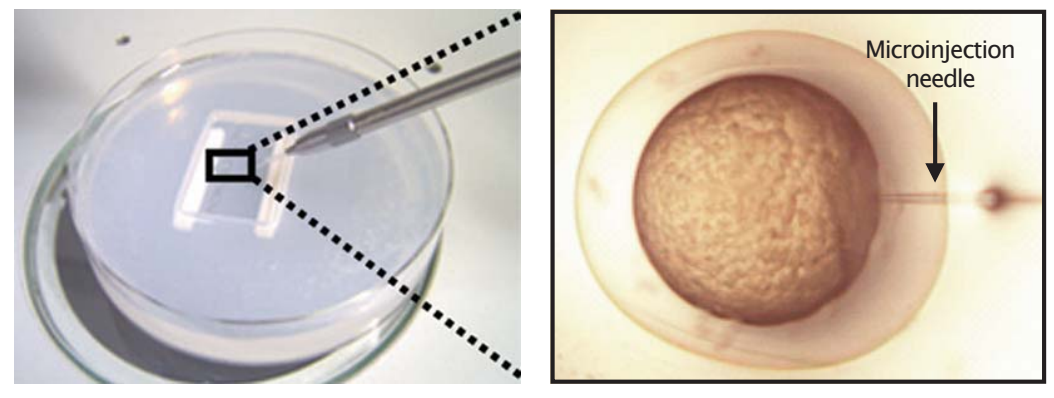

(A)

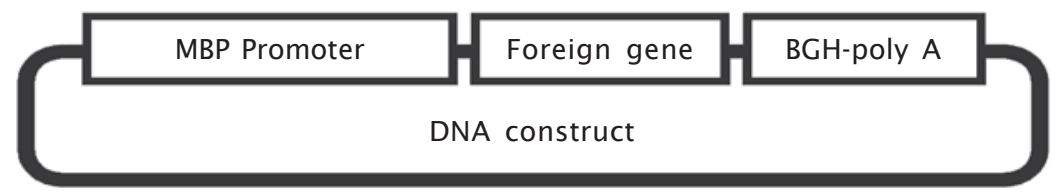

(B)

Figure 1. (A). An agarose gel plate (left figure) consists of twelve grooves that are used to support embryos (right figure) when penetrated by the microinjection needle (right figure, indicated by the arrow). (B). A plasmid DNA construct consisted of medaka $\beta$-actin promoter (mBP Promoter), foreign gene ( $\Delta 6$-desaturase-like, $\Delta 5$-desaturase-like, or elongase-like gene), and bovine growth hormone polyadenylation signal (BGH-polyA) 
construct (Figure $1 \mathrm{~b}$ ) in concentration of 30 $\mu \mathrm{g} / \mathrm{mL}$ in $0.1 \mathrm{M} \mathrm{KCl} / 0.125 \%$ tetramethylrhodamine dextran (Alimuddin, 2003). Transgenic individuals F0 were identified by PCR with DNA template that had been extracted from caudal fins. Isolation of genomic DNA was performed using a DNA Isolation Kit (Puregene, Minneapolis, MN) according to the manufacturer's instructions. PCR analysis was performed in $10 \mu \mathrm{L}$ of $10 x$ Ex Taq Buffer, $1 \mu \mathrm{l}$ of dNTPs, $0.05 \mu \mathrm{L}$ of Ex Taq polymerase (Takara, Shiga, Japan), $1 \mu \mathrm{L}$ of DNA as template and 1 pmol of each specific primer for foreign gene. Two microliters from the reaction were electrophoretically separated using $2 \%$ agarose gel, stained with ethidium bromide, and photographed under ultraviolet light. The mature fish carrying the transgene at their caudal fin was crossed with a non-transgenic zebrafish, and at least twenty 2-days-old larvae resulted from the process were pooled and used for genomic DNA isolation to identify the germ-line transmitter fish. The representative result of germ-line transgenic fish identification was shown in Figure 2. The germ-line positive F0 fish were then used to produce F1. Transgenic
F1 having high mRNA transcription levels analyzed by semi-quantitative reverse transcriptase PCR (sqRT-PCR) or real-time PCR were selected and used for production of F2 generation. Figure 3 demonstrated the representative results of transgene (Om $\triangle 5 F A D)$ expression in three strains of $F 1$ transgenic fish (Alimuddin et al., 2007). Production and screening procedures for $\mathrm{F} 1$ and $\mathrm{F} 2$ were the same as employed for F0. The transmission of transgene into F2 generation followed the Mendelian segregation pattern. The integration of the foreign gene into the host genome was also confirmed by Southern blotting analysis. Figure 4 showed representative result of Southern blotting analysis of transgenic fish carrying MELO gene. The hybridization signal was detected in transgenic fish and in the positive control. However, in the control fish (nontransgenic fish), no signals were detected (Figure 4C). In addition, Southern blot hybridization using undigested DNA of transgenic fish generated one high molecular weight signal (Figure 4, bottom photograph, arrow head). Migration of EtBr-stained genomic DNA signal was identical to the Southern blot hybridization

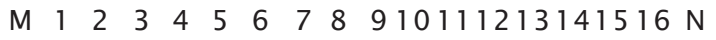

A
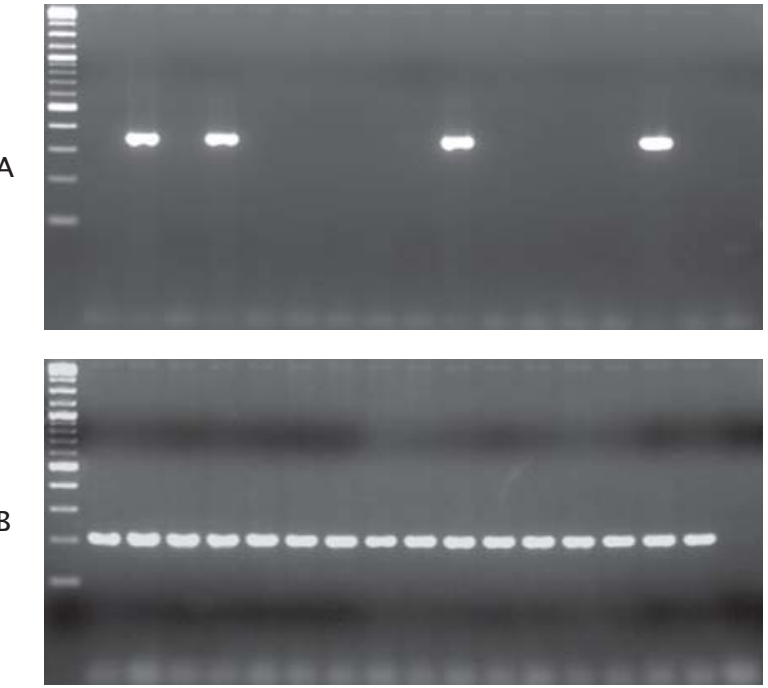

Figure 2. Result of F0 germ line transmitter screening by PCR analysis with DNA template extracted from pooled-larvae. DNA was extracted from twenty 2-days-old larvae obtained by crossing the DNA-positive F0 with non-transgenic individuals. (A). PCR product amplified using genomic DNA with Om $\triangle 6$ FAD gene specific primers. Lanes 1 through 16, PCR product amplified using genomic DNA samples from transgenic F0 individuals; lane N, a sample PCR product without DNA template. $M$ is 2-log ladder DNA marker (BioLabs, Inc., New England). The amplified fragment is 354-bp in size. (B) PCR product with b-actin gene primers [200-bp] 

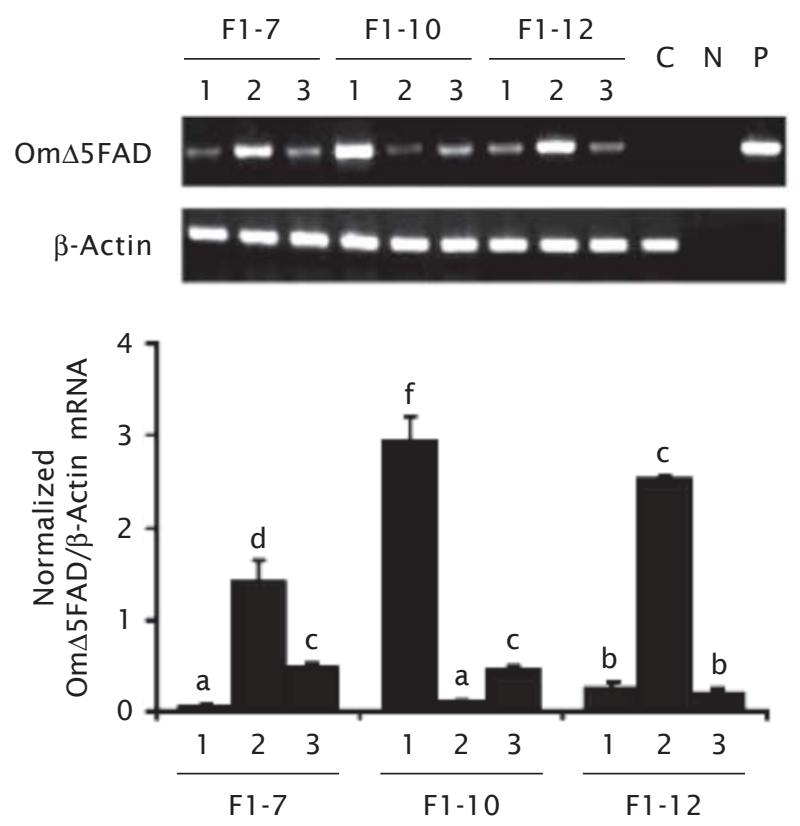

Figure 3. Representative transgene mRNA level in three strains of F1 transgenic fish carrying $\Delta 5$-desaturase-like ( $\Delta 5$-des) gene determined by semi-quantitative RT-PCR (sqRT-PCR; top figure) and real-time PCR (bottom figure). Three individual transgenic fish were analyzed from each strain. F1-7, F1-10, F112: F1 transgenic fish, with 7, 10, and 12 as the representative strains. Total RNA was extracted from caudal fin. The upper two sets of figures show the sqRT-PCR product of the $\Delta 5$-des ( 26 cycles) and $\beta$-actin ( 24 cycles) as internal control of cDNA loading. C, Control non-transgenic fish; $\mathrm{N}$, a sample PCR product without template; P, PCR product of plasmid DNA construct. The amount of $\triangle 5$-des mRNA analyzed by real-time PCR shown in the bottom figure was normalized to $\beta$-actin mRNA. The PCR template for the $\beta$-actin gene was diluted 100 -fold. Data are means \pm SD of each individual transgenic fish performed in triplicate PCR. Values with different letters are statistically significant at $(P<0.05)$ as determined by one-way ANOVA followed by Duncan's test

signal of undigested DNA. This result suggests that transgene had been integrated into the genome of the host. Comparison with the molecular weight size marker indicated that the signal was more than $30 \mathrm{~kb}$. There were $3 \mathrm{sig}$ nals observed in the positive control as open circular (top), linear (center), and supercoil forms (bottom).

\section{ANALYSIS OF EPA/DHA CONTENT}

Transgenic $\mathrm{F} 2$ and non-transgenic siblings used for fatty acid analysis were derived by crossing the transgenic F1 generation and wildtype fishes. They were maintained in the same aquaria and fed same diet, from larval to adult stage for about 3 months. Samples were taken after they were fasted for 36 hours. Total lipid was extracted from a pool of 3-4 adults in triplicate for each transgenic and non-transgenic sibling using the chloroform-methanol (2:1) method as described by Folch et al. (1957). Fatty acid methyl esters were prepared and analyzed by gas liquid chromatography as described by Alimuddin et al. (2005).

\section{Transgenic Fish Carrying Om $\Delta 6$ FAD Gene}

Total lipid content and n-3 fatty acids compositions of the experimental fish were shown in Table 1. There was no significant difference $(P>0.05)$ in the amount of total lipid in nontransgenic and transgenic fish. The EPA con- 

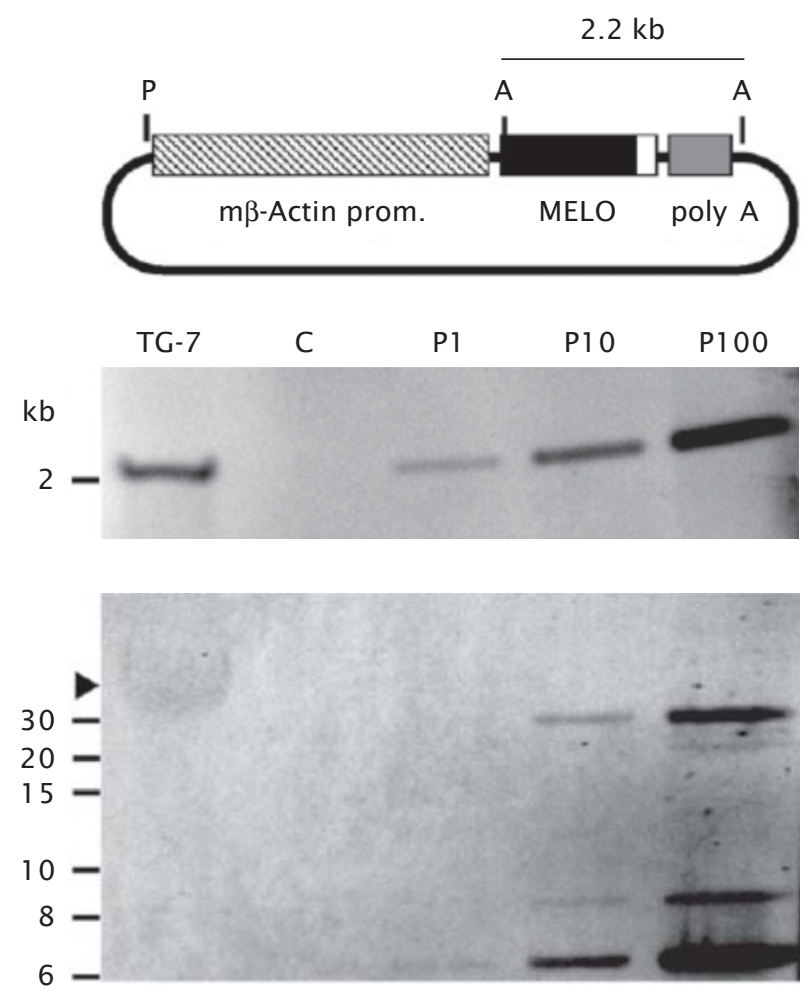

Figure 4. Restriction map of MELO gene construct (9 kb) (top), Southern blot analysis of Apal digested (center) and undigested zebrafish DNA (bottom). Apal-digested and undigested DNA $(10 \mu \mathrm{g})$ was electrophoresed on each lane and hybridized with PCR DIG-labeled $1.4 \mathrm{~kb}$ of MELO fragment (black shadow). $\mathrm{m} \beta$-Actin prom, medaka $\beta$-Actin promoter; MELO, masu salmon fatty acid elongase-like gene; $P$, Pstl; A, Apal; TG-7, DNA F2-7 transgenic fish. C is a negative control containing DNA from non-transgenic zebrafish. $\mathrm{P} 1, \mathrm{P} 10$ and $\mathrm{P} 100$ are positive controls of DNA from non-transgenic zebrafish containing the equivalent of 1,10 and 100 copies of transgene per cell, respectively. Arrow head is Southern blot hybridization signal of undigested DNA

tent in whole body of transgenic fish (strain 15-2) having high transgene expression level was 1.4 fold ( 1.86 vs. $1.32 \mathrm{mg} / \mathrm{g}$ ), docosapentaenoic acid (DPA) was 2.6 fold ( 0.66 vs. $0.25 \mathrm{mg} / \mathrm{g}$ ), and that of DHA was 2.1 fold (4.62 vs. $2.22 \mathrm{mg} / \mathrm{g})$ higher $(\mathrm{P}<0.05)$ than those in non-transgenic fish. About $75 \%(1.40 \mathrm{mg} / \mathrm{g})$, $86 \%(0.57 \mathrm{mg} / \mathrm{g})$, and $79 \%(3.63 \mathrm{mg} / \mathrm{g})$ of EPA, DPA, and DHA was distributed in muscle, respectively. There was a difference in the amount of EPA, DPA and DHA produced between the transgenic lines (strains 10-1 and 15-2). This may be caused by different expression of transgene in muscle. The transgenic fish appeared to be normal, healthy and indistinguishable from non-transgenic zebrafish at least in their external morphology.
While the EPA and DHA contents of transgenic fish carrying the Om $\triangle 6 F A D$ gene dramatically rose, there was a decrease in the LNA content, particularly in the transgenic 15 2 strain. This suggested that the transgene has been active in the conversion of LNA, resulting in greater amount of the highly unsaturated fatty acids. A high expression of foreign $\mathrm{Om} \triangle 6 \mathrm{FAD}$ in transgenic fish may also stimulate the endogenous gene expression in the subsequent pathways, thereby increasing the levels of the end products. In fact, it has been reported that the activity of an enzyme involved earlier in the desaturation/elongation pathway of the fatty acid metabolism in turbot cell line affected the apparent activity of a subsequent enzyme (Ghioni et al., 1999). In 


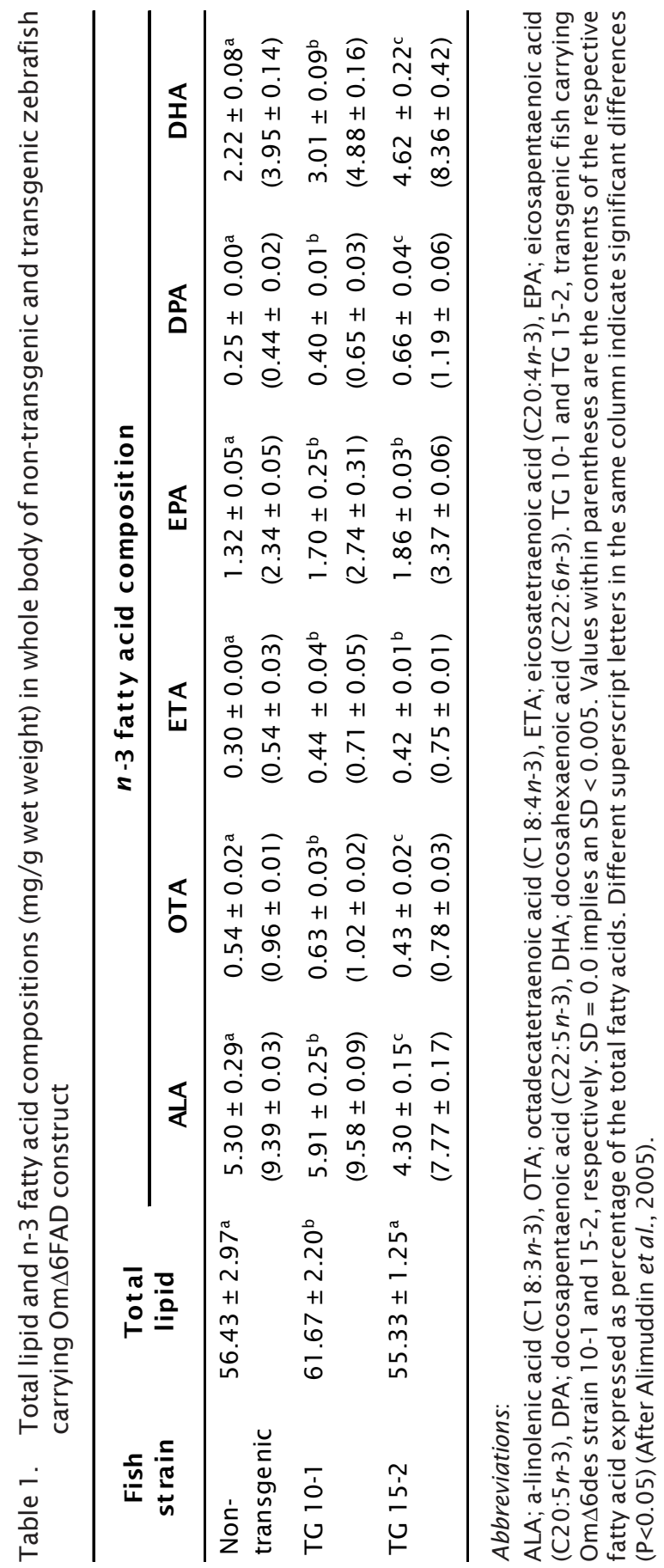


addition, we had also isolated another form of desaturase-like gene from masu salmon (GenBank accession number: AB074149) that is phylogenetically clustered together with $\Delta 6$ desaturase-like gene from rainbow trout and $\Delta 5$-desaturase gene from Atlantic salmon (Zheng et al., 2004). Comparison of fatty acid contents in transgenic zebrafish with different forms of desaturase-like genes from masu salmon may clarify the specific activity of those desaturase-like genes. Further, whether the OmD6FAD used in this study has a D5desaturase activity such as zebrafish desaturase (Hasting et al., 2001) remains to be elucidated.

\section{Transgenic Fish Carrying Om $\Delta 5$ FAD Gene}

Total lipid content and n-3 fatty acids compositions of the fish fed with commercial diet and Artemia nauplii or solely of Artemia nauplii are shown in Tables 2 and 3, respectively. There was no significant difference $(P>0.05)$ in the amount of total lipid in non-transgenic and transgenic fish. The EPA content in whole body of transgenic fish (F2-10 strain) was 1.21fold (6.05 versus $4.99 \mathrm{mg} / \mathrm{g}$ ), DPA was 1.17 fold ( 1.26 versus $1.08 \mathrm{mg} / \mathrm{g})$, and that of DHA was 1.24 -fold ( 11.01 versus $8.87 \mathrm{mg} / \mathrm{g}$ ) higher $(\mathrm{P}<0.05)$ than those in non-transgenic fish. The same patterns were obtained in transgenic fish fed only with Artemia nauplii. The amount of EPA in transgenic fish (F2-10 strain) fed Artemia nauplii increased by 1.14-fold (1.57 versus 1.38 $\mathrm{mg} / \mathrm{g}$ ), DPA by 1.11 -fold (0.62 versus $0.56 \mathrm{mg} /$ g) and DHA by 1.13 -fold (2.31 versus $2.04 \mathrm{mg} /$ g) compared with non-transgenic fish. The transgenic zebrafish appear to be normal, healthy and indistinguishable from their nontransgenic counterparts at least in their external morphology other than body size.

Increased in EPA and DHA contents of transgenic fish carrying the Om $\triangle 5 F A D$ gene, while the ETA content decreased, particularly in F2-10 and F2-12 strains suggests that the transgene possess a $\Delta 5$-desaturase enzyme activity, involving the desaturation of ETA. Further, the amount of LNA was similar between transgenic and non-transgenic fish. On the contrary, in our earlier study, the amount of LNA in transgenic fish carrying Om $\triangle 6 F A D$ decreased, while the ETA content increased (Alimuddin et al., 2005). It is therefore confirmed that the two desaturases encoded by genes isolated from masu salmon carry distinct characteristics, at least in their substrate prefer- ences. Nevertheless, it remains to be clarified whether the Om $\triangle 5 F A D$ used in this study has bi-functional desaturase enzyme activity like the zebrafish $\Delta 5 / \Delta 6$-desaturase (Hasting et al., $2001)$ or is predominant as $\Delta 5$-desaturase. Transgenic fish expressing Om $\triangle 5 F A D$-like gene could produce greater amounts of EPA and DHA (1.21-fold and 1.24-fold respectively). In the previous study, over-expression of masu salmon Om $\triangle 6 F A D$ gene in zebrafish increased the production levels of EPA by 1.41 -fold and DHA by 2.1 -fold (Alimuddin et al., 2005). Higher augmentation of EPA and DHA production in transgenic zebrafish carrying Om $\triangle 6 \mathrm{FAD}$ than that of Om $\triangle 5 F A D$ suggested that $\Delta 6$-desaturase enzyme activity may be the rate-limiting step of EPA/DHA biosynthesis in zebrafish.

A high level of EPA and DHA content in transgenic fish may be of physiological advantage for fish. In the present study, a tendency for higher body weights among male transgenic fish fed both with commercial feed and Artemia nauplii, and Artemia nauplii alone was observed in comparison with nontransgenic fish. Additionally, transgenic fish fed with the commercial diet and Artemia produced greater amounts of EPA/DHA compared with fish fed entirely on Artemia nauplii and this probably caused an increase in body weight (Figure 5). Thus, the improvement of EPA/DHA contents in transgenic fish fashioned their superior growth. It is well established that the inclusions of the two fatty acids in fish diets improve the growth and normal development of several aquaculturally important fish larvae (Watanabe, 1993; Furuita et al., 2000; Copeman et al., 2002; Watanabe \& VassalloAgius, 2003; Mazorra et al., 2003). Therefore, it is conceivable that transgenic fish producing high level of EPA/DHA could probably become a promising development in aquaculture in terms of accelerating fish growth.

\section{Transgenic Fish Carrying MELO Gene}

Formation of EPA/DHA from precursor LNA requires two or more different desaturases and at least three elongases capable of utilizing polyunsaturated fatty acids as substrates. It is generally known that fatty acid desaturases, $\Delta 6$-desaturase, and/or $\Delta 5$-desaturase are the rate-limiting step in HUFA biosynthesis. However, the involvement of elongase as the key enzyme has been demonstrated in turbot, Scophthalmus maximus (Ghioni et al., 1999), and recently in cod, Gadus morhua (Agaba et al., 2005). This may be implicated in the inabil- 


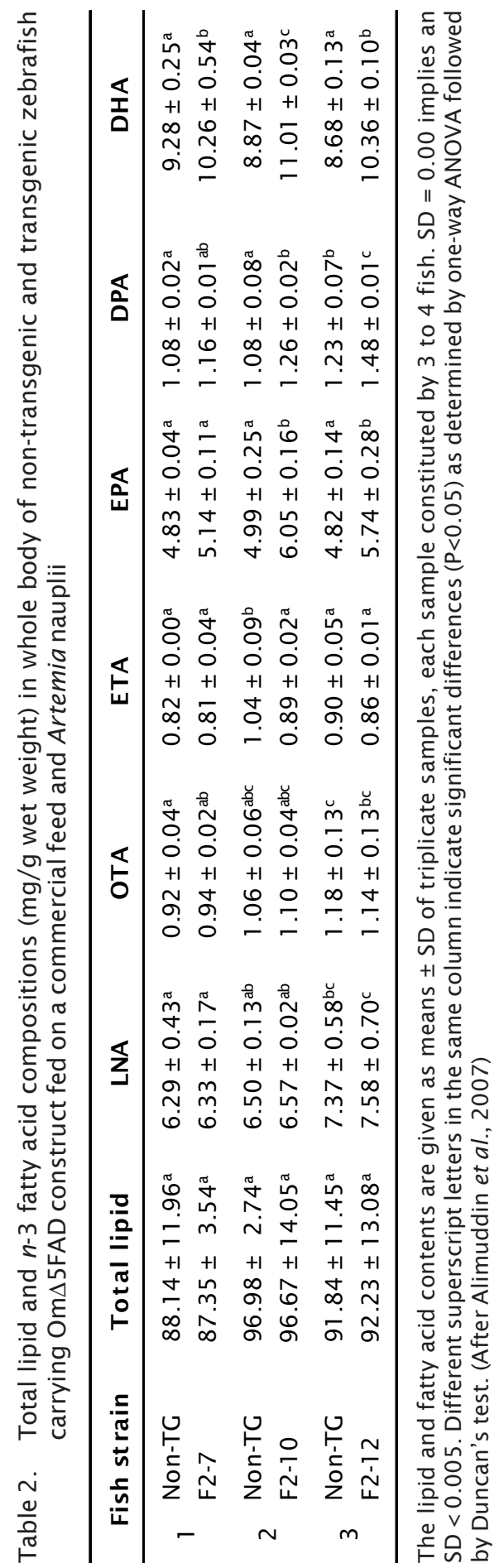








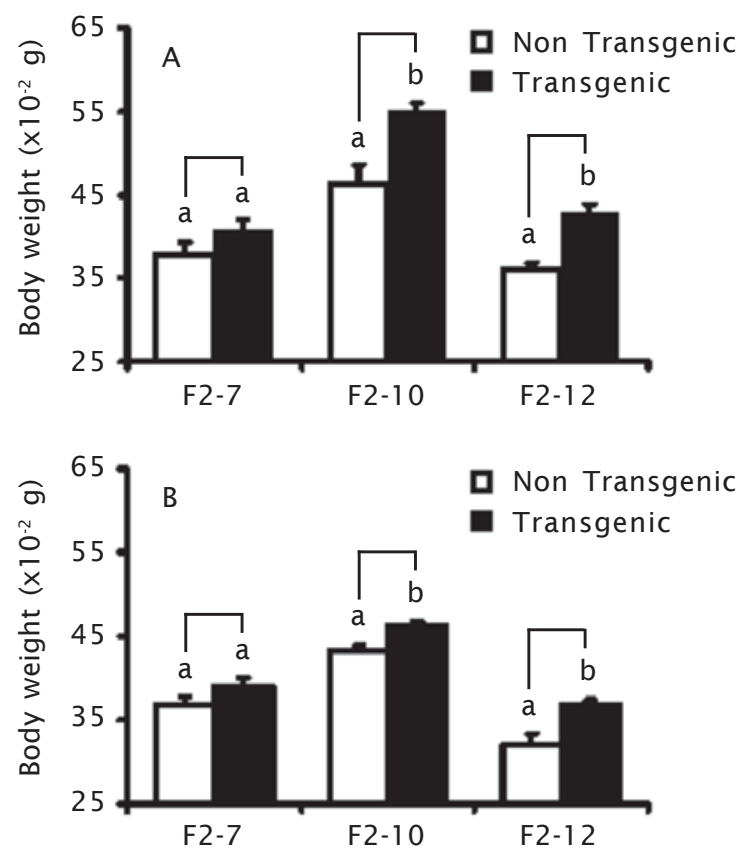

Figure 5. Final body weight of male transgenic and non-transgenic fish fed with commercial diet and Artemia nauplii (A) or Artemia nauplii only (B). F2-7, F2-10, F2-12: F2 transgenic fish, with 7, 10, and 12 as the representative strains. Data represented are means \pm SD of male body weight $(n \geq 10)$. Values with different letters are statistically significant at $\mathrm{P}<0.05$ as determined by one-way ANOVA test (After Alimuddin et al., 2007)

ity of some marine fishes to synthesize EPA/ DHA, and perhaps the introduction of a foreign elongase gene could be a powerful approach to complete this critical step. Production of transgenic marine fish carrying various fatty acid metabolic enzymes holds exciting possibilities for the future of aquaculture. As the first step towards generation of transgenic marine fish, we cloned and over-expressed a masu salmon (Oncorhynchus masou) MELO gene in the model species zebrafish (Danio rerio). Based on the predicted topology, consensus sequences, and sequence homologies, MELO are in excellent agreement with expected structural traits of elongases (Leonard et al., 2002; Hasting et al., 2004; Meyer et al., 2004; Agaba et al., 2004, 2005).

Total lipid content and n" 3 fatty acid compositions of the fish are shown in Table 4. There was no significant difference $(P<0.05)$ in the amount of total lipid in transgenic and non-transgenic fish for all fish groups. In contrast, fatty acid contents were generally different between transgenic and non-transgenic fish, except for LNA (Table 4). The amount of OTA in whole body of the transgenic F2-3 strains decreased ( 1.65 versus $1.81 \mathrm{mg} / \mathrm{g}$ ), while it was comparable for the remaining strains. The ETA content in whole body of transgenic fish (F2-3 strain) was 1.14-fold (1.24 versus $1.09 \mathrm{mg} / \mathrm{g}$ ), EPA was 1.30-fold (1.53 versus $1.18 \mathrm{mg} / \mathrm{g}$ ), DPA was 1.57 -fold (0.86 versus $0.54 \mathrm{mg} / \mathrm{g})$, and that of DHA was 1.33 -fold (2.79 versus $2.10 \mathrm{mg} / \mathrm{g})$ higher $(\mathrm{P}<0.05)$ than those in non-transgenic fish. Similar variation patterns were observed for fatty acid contents in transgenic F2-7 and F2-8 strains (Table 4). The transgenic zebrafish appeared to be normal, healthy, and indistinguishable from their nontransgenic counterparts, at least in their external morphology.

\section{FUTURE ASPECTS}

Up to date, we had generated three types of transgenic fish strains that carry either OmD6FAD (Alimuddin et al., 2005), OmD5FAD (Alimuddin et al., 2007), and MELO (Alimuddin et al., 2008). Generation of double- or triple- 


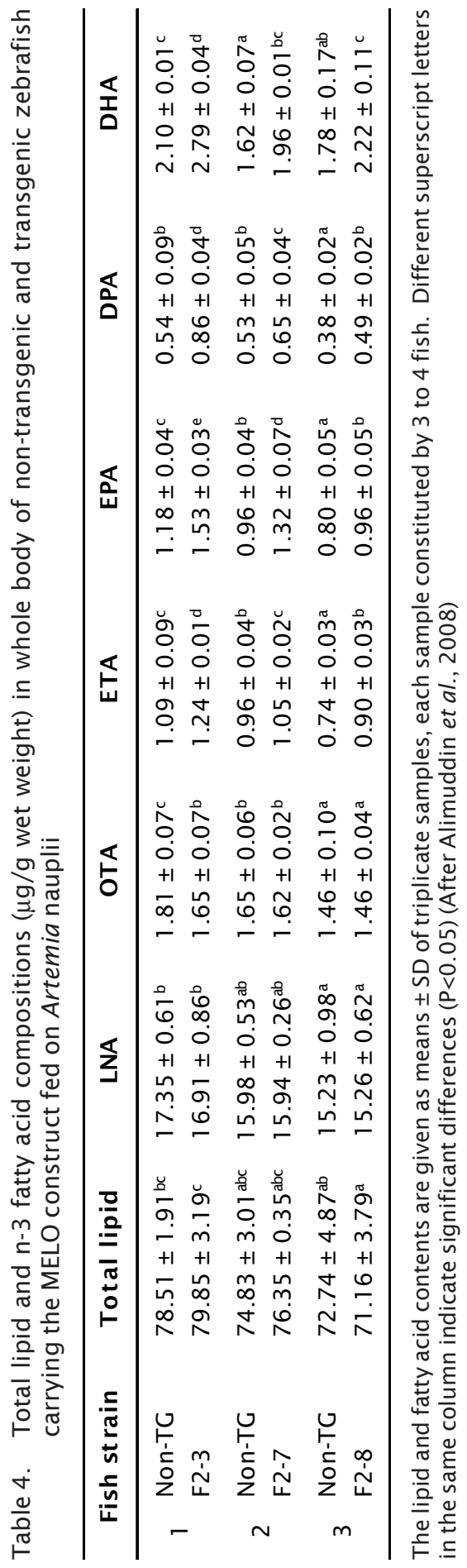


transgenic fish may produce more EPA and DHA than a single-transgenic strain. Further, D4desaturase gene involved in the conversion of DPA directly to DHA has been isolated from protist Thraustochytrium sp. (Qiu et al., 2001), microalga Euglena gracilis (Meyer et al., 2003) and Pavlova lutheri (Tonon et al., 2003). Transgenic fish carrying this D4-desaturase gene may produce more DHA than the natural pathway. In aquaculture, application of this technique would open the possibility of eliminating fish oils in fish diets, besides avoiding the necessity for altered dietary regimes prior to marketing. In the long run, this also may allow the growing aquaculture industry to depend less on ocean fisheries stocks for ingredients for aquatic diets as well as helping to promote the safety of fish-based food.

\section{REFERENCES}

Agaba, M., Tocher, D.R., Dickson, C.A., Dick, J.R., and Teale, A.J. 2004. Zebrafish cDNA encoding multifunctional fatty acid elongase involved in production of eicosapentaenoic (20:5n-3) and docosahexaenoic (22:6n-3) acids. Mar. Biotechnol. 6: 251 -261.

Agaba, M., Tocher, D.R., Zheng, X., Dickson, C.A., Dick, J.R., and Teale, A.J. 2005. Cloning and functional characterization of polyunsaturated fatty acid elongases of marine and freshwater teleost fish. Comp. Biochem. Physiol. 6: 251--261.

Alimuddin. 2003. Introduction and expression of foreign Ä6-desaturase-like gene in a teleostean fish. Master Thesis. Tokyo University of Fisheries. Japan.

Alimuddin, Yoshizaki, G., Kiron, V., Satoh, S., and Takeuchi, T. 2005. Enhancement of EPA and DHA biosynthesis by over-expression of masu salmon Ä6-desaturase-like gene in zebrafish. Transgenic Res. 14: 159-165.

Alimuddin, Yoshizaki, G., Kiron, V., Satoh, S., and Takeuchi, T. 2007. Expression of masu salmon Ä5-desaturase-like gene elevated EPA and DHA biosynthesis in zebrafish. Mar. Biotechnol. 9: 92-100.

Alimuddin, Kiron, V., Satoh, S., Takeuchi, T., and Yoshizaki, G. 2008. Cloning and expression of masu salmon elongase-like gene in zebrafish. Aquaculture. 282: 13--18.

Bell, J.G., Henderson, R.J., Tocher, D.R., McGhee, F., Dick, J.R., Porter, A., Smullen, R.P., and Sargent, J.R. 2002. Substituting fish oil with crude palm oil in the diet of Atlantic salmon (Salmo salar) affects muscle fatty acid composition and hepatic fatty acid metabolism. J. Nutr. 132: 222--230.

Bell, J.G., McEvoy, J., Tocher, D.R., McGhee, F., Campbell, P.J., and Sargent, J.R. 2001. Replacement of fish oil with rapeseed oil in diets of Atlantic salmon (Salmo salar) affects tissue lipid compositions and hepatocyte fatty acid metabolism. J. Nutr. 131 : 1,535-1,543.

Bell, J.G., McGhee, F., Dick, J.R., and Tocher, D.R. 2005. Dioxin and dioxin-like polych lorinated biphenyls (PCBs) in Scottish farmed salmon (Salmo salar): effects of replacement of dietary marine fish oil with vegetable oils. Aquaculture, 243: 305--314.

Brenner, R.R. 1977. Regulatory function of D6 desaturase: a key enzyme of polyunsaturated fatty acid synthesis. Adv. Exp. Med. Biol. 83: 85--101.

Buzzy, M., Henderson, R.J., and Sargent, J.R. 1996. The desaturation and elongation of linolenic acid and eicosapentaenoic acid by hepatocytes and liver microsomes from rainbow trout (Oncorhynchus mykiss) fed diets containing fish oil or olive oil. Biochim. Biophys. Acta. 1,299: 235--244.

Buzzy, M., Henderson, R.J., and Sargent, J.R. 1997. Biosynthesis of docosahexaenoic acid in trout hepatocytes proceeds via 24-carbon intermediates. Comp. Biochem. Physiol. 116: 263--267.

Carvan, M.J. $3^{\text {rd }}$, Dalton, T.P., Stuart, G.W., and Nebert, D.W. 2000. Transgenic zebrafish as sentinels for aquatic pollution. Ann. N.Y. Acad. Sci. 91 9: 133--147.

Cavari, B., Funkenstein, B., Chen, T.T., GonzalesVillasenor, L.I., and Schartl, M. 1993. Effect of growth hormone on the growth rate of gilthead seabream (Sparus aurata), and the use of different constructs for the production of transgenic fish. Aquaculture. 111 : 189--197.

Chen, T.T., Kight, K., Lin, C.M., Powers, D.A., Hayat, M., Chatakondi, N., Raboux, A.C., Duncan, P.L., and Dunham, R.A. 1993. Expression and inheritance of RSVLTR-rtGH 1 complementary DNA in the transgenic common carp, (Cyprinus carpio). Mol Mar. Biol. Biotechnol. 2: 88--95.

Cho, H.P., Nakamura, M.T., and Clarke, S.D. 1999. Cloning, expression, and nutritional regulation of the mammalian D6 desaturase. J. Biol. Chem. 274: 471--477. 
Chourrout, D., Guyomard, R., and Houdebine, L.M. 1986. High efficiency gene transfer in rainbow trout (Salmo gairdneri Rich.) by microinjection into egg cytoplasm. Aquaculture. 51: 143--150.

Cole, G.M., Lim, G.P., Yang, F., Teter, B., Begum, A., Ma, Q., Harris-White, M.E., and Frautschy, S.A. 2005. Prevention of Alzheimer's disease: omega-3 fatty acid and phenolic antioxidant interventions. Neurobiol. Aging. 26S: 133--136.

Copeman, L.A., Parrish, C.C., Brown, J.A., and Harel, M. 2002. Effects of docosahexaenoic, eicosapentaenoic, and arachidonic acids on the early growth, survival, lipid composition and pigmentation of yellowtail flounder (Limanda ferruginea): a live food enrichment experiment. Aquaculture. $210:$ 285--304.

Devlin, R.H., Yesaki, T.Y., Biagi, C.A., Donaldson, E.M., Swanson, P., and Chan, W.K. 1994. Extraordinary salmon growth. Nature. 371 : 209--210.

Devlin, R.H. 1997. Transgenic salmonids. In: Transgenic Animals (L.M. Houdebine, Ed.), Harwood Academic Publishers, Amsterdam, Netherlands. p. 105--117.

Dunham, R.A., Eash, J., Askins, J., and Townes, T.M. 1987. Transfer of the metallothioneinhuman growth hormone fusion gene into channel catfish. Trans. Am. Fish. Soc. 116 : 87--91.

Dunham, R.A., Raboux, A.C., Duncan, P.L., Hayat, M., Chen, T.T., Lin, C.M., Kight, K., GonzalezVillasenor, I., and Powers, D.A. 1992. Transfer, expression and inheritance of salmonid growth hormone in channel catfish, Ictalurus punctatus, and effects on performance traits. Mol. Mar. Biol. Biotechnol. 1: 380--389.

Dunham, R.E., G.W. Warr, A. Nicholas, P.L. Duncan, B. Argue, D. Middleton, and H. Kucuktas. 2002. Enhanced bacterial disease resistance of transgenic channel catfish Ictalurus punctatus possessing cecropin genes. Mar. Biotechnol. 4: 338--344.

FAO. 2001. Aquaculture in the Third Millenium. Available from http://www.fao.org/fi/ meetings/aq2000/tech_proc/third_ mill.asp.

Folch, J., Lee, M., and Sloane-Stanley, G.H. 1957. A simple method for the isolation and purification of total lipids from animal tissues. J. Biol. Chem. 266: 497-509.

Furuita, H., Tanaka, H., Yamamoto, T., Shiraishi,
M., and Takeuchi, T. 2000. Effects of $n-3$ HUFA levels in broodstock diet on the reproductive performance and egg and larval quality of the Japanese flounder, Paralichthys olivaceus. Aquaculture. 187: 387--398.

Garcio-Poso, S., Bejar, J., Shaw, M., and Alvarez, M.C. 1998. Effect of exogenous DNA microinjection on early development response of the sebream (Sparus auratus). Mol. Mar. Biol. Biotecnol. 7: 248--258.

Ghioni, C., Tocher, D.R., Bell, M.V., Dick, J.R., and Sargent, J.R. 1999. Low C1 8 to C20 fatty acid elongase activity and limited conversion of stearidonic acid, 18:4(n-3), to eicosapentaenoic acid, 20:5(n-3), in a cell line from the turbot, Scopthalmus maximus. Biochim. Biophys. Acta. 1,437: 170--181.

Gong, Z. 1999. Zebrafish expressed sequence tags and their applications. Methods Cell Biol. 60: 213--233.

Gong, Z. 2003. Generation of living color transgenic zebrafish. In: Step toward a Great Future (Shimizu, N., Aoki, T., Hirono, I., and Takashima, F., Eds.), p. 329--229.

Gross, M.L., Scheider, J.F., Moav, B., Moav, N., Alvarez, C., Myster, S.H., Liu, Z., Hallerman, E.M., Hackett, P.B., Guise, K.S. Faras, A.J., and Kapuscinski, A.R. 1992. Molecular analysis and growth evaluation of northern pike (Esox lucius) microinjection with growth hormone genes. Aquaculture. 103: 253--273.

Hardman, W.E. 2004. (n"3) fatty acids and cancer therapy. J. Nutr. 134: 3427S-3430S.

Hasting, N., Agaba, M.K., Tocher, D.R., Zheng, X., Dickson, C.A., Dick, J.R., and Teale, A.J. 2004. Molecular cloning and functional characterization of fatty acyl desaturase and elongase cDNAs involved in the production of eicosapentaenoic and docosahexaenoic acids from alpha-linolenic acid in Atlantic salmon (Salmo salar). Mar. Biotechnol. 6: 463--474.

Hastings, N., Agaba, M., Tocher, D.R., Leaver, M.J., Dick, J.R., Sargent, J.R., and Teale, A.J. 2001. A vertebrate fatty acid desaturase with D5 and D6 activities. Proc. Natl. Acad. Sci. USA. 98: 14,304-14,309.

Henderson, R.J. 1996. Fatty metabolism in freshwater fish with particular references to polyunsaturated fatty acids. Arch. Anim. Nutr. 49: 5--22.

Hew, C.L. and Fletcher, G.L. 2001. The role of aquatic biotechnology in aquaculture. 
Aquaculture. 197: 191--204.

Higashijima, S., Okamoto, H., Ueno, N., Hotta, Y., and Eguchi, G. 1997. High frequency generation of transgenic zebrafish which reliably express GFP in whole muscles or the whole body by using promoters of zebrafish origin. Dev. Biol. 192: 289--299.

Hites, R.A., Foran, J.A., Carpenter, D.O., Hamilton, M.C., Knuth, B.A., and Schwager, S.J. 2004. Global assessment of organic contaminants in farmed salmon. Science. 303: 226--229.

Hwang, G., Muller, F., Rahman, M.A., Williams, D.W., Murdock, P.J., Pasi, K.J., Goldspink, G., Farahmand, H., and Maclean, N. 2004. Fish as bioreactors: transgene expression of human coagulation factor VII in fish embryos. Mar. Biotechnol. 6: 485--492.

Infante, J.P. and Huszagh, V.A. 1998. Analysis of the putative role of 24-carbon polyunsaturated fatty acids in the biosynthesis of docosapentaenoic (22:5n-6) and docosahexaenoic $(22: 6 n-3)$ acids. FEBS Letters. 431: 1--6.

Ishizaki, Y., Matsuda, R., Uematsu, K., Shimizu, K., Arimoto, M., and Takeuchi, T. 2001. The effect of dietary docosahexaenoic acid on schooling behavior and brain development in larval yellowtail. J. Fish Biol. 58: 1,6911,703 .

Jacobs, M.N., Ferrario, J., and Byrne, C. 2002a. Investigation of polychlorinated dibenzop-dioxins dibenzo-p-furans and selected coplanar biphenyls in Scottish farmed Atlantic salmon (Salmo salar). Chemosphere. 47: 183--191.

Jacobs, M.N., Covaci, A., and Schepens, P. $2002 \mathrm{~b}$. Investigation of selected persistant organic pollutants in farmed Atlantic salmon (Salmo salar), salmon aquaculture feed, and fish oil components of the feed. Environ. Sci. Technol. 36: 2,797-2,805.

Kiron, V., Fukuda, H., Takeuchi, T., and Watanabe, T. 1995. Essential fatty acid nutrition and defence mechanisms in rainbow trout Oncorhynchus mykiss. Comp. Biochem. Physiol. 111:361--367.

Kobayashi, S.--., Alimuddin, Morita, T., Endo, M., Takeuchi, T., and Yoshizaki, G. 2007. Transgenic Nile tilapia (Oreochromis niloticus) over-expressing growth hormone show reduced ammonia excretion. Aquaculture. 270: 427--435.

Koven, W., Barr, Y., Lutzky, S., Ben-Atia, I., Weiss, R., Harel, M., Behrens, P., and Tandler, A.
2001. The effect of dietary arachidonic acid $(20: 4 n-6)$ on growth, survival and resistance to handling stress in gilthead seabream (Sparus aurata) larvae. Aquaculture. 193: 107--122.

Lauritzen, L., Hansen, H.S., Jorgensen, M.H., and Michaelsen, K.F. 2001. The essentiality of long chain $n-3$ fatty acids in relation to development and function of the brain and retina. Prog. Lipid Res. 40: 1--94.

Leonard, A.E., Kelder, B., Bobik, E.G., Chuang, L.T., Lewis, C.J., Kopchik, J.J., Mukerji, P., and Huang, Y.S. 2002. Identification and expression of mammalian long-chain PUFA elongation enzymes. Lipid. 37: 733-740.

Lu, J.K., Chen, T.T., Allen, S.K., Matsubara, T., and Burns, J.C. 1996. Production of transgenic dwarf surfclams, Mulina lateralis, with pantropic retroviral vectors. Proc. Natl. Acad. Sci. USA. 93: 3,482-3,486.

Martinez, R., Estrada, M.P., Berlanga, J., Guillen, I., Hernandez, O., Cabrera, E., Pimentel, R., Morales, R., Herrera, F., Morales, A., Pina, J.C., Abad, Z., Sanchez, V., Melamed, P., Lleonart, R., and de la Fuente, J. 1996. Growth enhancement in transgenic tilapia by ectopic expression of tilapia growth hormone. Mol. Mar. Biol. Biotechnol. 5: 62-70.

Mazorra, C., Bruce, M.P., Bell, J.G., Davie, A., Alorend, E., Jordan, N., Rees, J., Papanikos, N., Porter, M., and Bromage, N. 2003. Dietary lipid enhancement of broodstock reproductive performance and egg and larval quality in Atlantic halibut (Hippoglossus hippoglossus). Aquaculture. 227: $21--33$.

Melamed, P., Gong, Z., Fletcher, G., and Hew, C.L. 2002. The potential impact of modern biotechnology on fish aquaculture. Aquaculture, 204: 255--269.

Meyer, A., Kirsch, H., Domergue, F., Abbadi, A., Sperling, P., Bauer, J., Cirpus, P., Zhank, T.K., Moreau, H., Roscoe, T.J., Zähringer, U., and Heinz, E. 2004. Novel fatty acid elongases and their use for the reconstitution of docosahexaenoic acid biosynthesis. J. Lipid Res. 45: 1,899-1,909.

Morita, T., Yoshizaki, G., Kobayashi, M., Watabe, S., and Takeuchi, T. 2004. Fish eggs as bioreactors: the production of bioactive luteinizing hormone in transgenic trout embryos. Transgenic Res. 13: 551--557.

Morita, T., Yoshizaki, G., Takeuchi, T., and Kobayashi, M. 2005. Production of pharma- 
ceutical proteins in fish eggs. Nippon Suisan Gakkaishi. 71 (5): 837 (In Japanese).

Mourente, G. and Tocher, D.R. 1994. In vivo metabolism of $\left[1-{ }^{-14} \mathrm{C}\right]$ linolenic acid $(18: 3$ ( $n$ 3)) and $\left[1-{ }^{14} \mathrm{C}\right]$ eicosapentaenoic acid $(20: 5(n-3))$ in a marine fish: time-course of the desaturation/elongation pathway. Biochim. Biophys. Acta, 1,212: 109--1 18.

Myers, R.A. and Worm, B. 2003. Rapid worldwide depletion of predatory fish communities. Nature. 423: 280--283.

Nakatsuji, T. 2000. The ice goby (Shiro-uo), Leucopsarion petersii, as a new model for studying fish embryogenesis and transgenesis. Proceeding of the Molecular Mechanisms of Morphogenesis in the Early Development of Fish. p. 9--10.

Nam, Y.K., Noh, J.K., Cho, Y.S., Cho, H.J., Cho, K.N., Kim, C.G., and Kim, D.S. 2001. Dramatically accelerated growth and extraordinary gigantism of transgenic mud loach Misgurnus mizolepis. Transgenic Res. 10: 353--362.

Nugent, A.P. 2004. The metabolic syndrome. Nutrition Bulletin. 29: 36--43.

Opsahl-Ferstad, H.-G., Rudi, H, Ruyter, B., and Refstie S. 2003. Biotechnological approaches to modify rapeseed oil composition for applications in aquaculture. Plant Science. 165: 349--357.

Pitkanen, T.I., Krasnov, A., Reinisalo, M., and Molsa, H. 1999. Transfer and expression of glucose transporter and hexokinase genes in salmonid fish. Aquaculture. 173: 319--332.

Pohajdak, B., Mansour, M., Hrytsenko, O., Conlon, J.M., Dymond, L.C., and Wright, J.R. Jr. 2004. Production of transgenic tilapia with Brockmann bodies secreting [desThrB30] human insulin. Transgenic Res. 13: 313--323.

Powers, D.A., Hereford, L., Cole, T., Chen, T.T., Lin, C.M., Night, K., Creech, K., and Dunham, R. 1992. Electroporation: a method for transferring genes into the gametes of zebrafish (Brachidonio rerio), channel catfish (Ictalurus punctatus), and common carp (Cyprinus carpio). Mol. Mar. Biol. Biotechnol. 1: 301--308.

Powers, D.A., Kirby, V.L., Cole, T., and Hereford, L. 1995. Electroporation as an effective means of introducing DNA into abalone (Haliotis rufescens). Mol. Mar. Biol. Biotechnol. 4: 369--375.

Qiu, X., Hong, H., and MacKenzie, S.L. 2001.
Identification of a D4 fatty acid desaturase from Thraustochytrium sp. involved in the biosynthesis of docosahexanoic acid by heterologous expression in Saccharomyces cerevisiae and Brassica juncea. J. Bio. Chem. 276: 31,561-31,566.

Rahman, M.A., Mak, R., Ayad, H., Smith, A., and Maclean, N. 1998. Expression of a novel piscine growth hormone gene results in growth enhancement in transgenic tilapia (Oreochromis niloticus). Transgenic Res. 7: 357--369.

Rivers, J.P., Sinclair, A.J., and Crawford, M.A. 1975. Inability of the cat to desaturate essentially fatty acids. Nature. 285: 171--173.

Sarmasik, A., Jang, I.-K., Chun, C.Z., Lu, J.K., and Chen, T.T. 2001. Production of transgenic live-bearing fish and crustaceans produced by transforming immature gonads with replication-defective pantropic retroviral vectors. Mar. Biotechnol. 3: 470-477.

Sarmasik, A., Warr, G., and Chen, T.T. 2002. Production of transgenic medaka with increased resistance to bacterial pathogens. Mar. Biotechnol. 4: 310-322.

Seiliez, I., Panserat, S., Corraze, G., Kaushik, S., and Bergot, P. 2003. Cloning and nutrional regulation of a D6-desaturase-like enzyme in the marine teleost gilthead seabream (Sparus aurata). Comp. Biochem. Physiol. 135: 449--460.

Seiliez, I., Panserat, S., Kaushik, S., and Bergot, P. 2001. Cloning, tissue distribution and nutritional regulation of a D6 desaturaselike enzyme in rainbow trout. Comp. Biochem. Physiol. 130: 83--93.

Simopoulos, A.P. 2002. Omega-3 fatty acids in inflammation and autoimmune disease. $J$. Am. Coll. Nutr. 21 : 495--505.

Sprecher, H. 2000. Metabolism of highly unsaturated n-3 and n-6 fatty acids. Biochim. Biophys. Acta. 1,486: 219--231.

Sprecher, H. 1981. Biochemistry of essential fatty acids. Prog. Lipid Res. 20: 13--22.

Takagi, S., Sasado, G., Tamiya, G., Ozato, K., Wakamatsu, Y., Takeshita, A., and Kimura, M. 1994. An efficient expression vector for transgenic medaka construction. Mol. Mar. Biol. Biotechnol. 3: 192--199.

Takeuchi, T. 2001. A review of feed development for early life stages of marine finfish in Japan. Aquaculture. 200: 203--222.

Tocher, D.R. and Sargent, J.R. 1990. Incorporation into phospholipids classes and me- 
tabolism via desaturation and elongation of various ${ }^{14} \mathrm{C}$-labeled $n-3$ and $n-6$ polyunsaturated fatty acids in trout astrocytes in primary culture. J. Neurochem. 542: 118 -124.

Tocher, D.R., Bell, J.G., Henderson, R.J., McGhee, F., Mitchell, D., and Morris, P.C. 2000. The effect of dietary linseed and rapeseed oils on polyunsaturated fatty acid metabolism in Atlantic salmon (Salmo salar) undergoing parr-smolt transformation. Fish Physiol. Biochem. 23: 59--73.

Tocher, D.R., Leaver, M.J., and Hodgson, P.A. 1998. Recent advances in the biochemistry and molecular biology of fatty acyl desaturases. Prog. Lipid Res. 37: 73--117.

Tonon, T., Harvey, D., Larson, T.R., and Ian A. Graham, I.A. 2003. Identification of a very long chain polyunsaturated fatty acid D4desaturase from the microalga Pavlova lutheri. FEBS Letters. 553: 440--444.

Tonon, T., Sayanova, O., Michaelson, L.V., Qing, R., Harvey, D., Larson, T.R., Li, Y., Naiper, J.A., and Graham, A. 2005. Fatty acid desaturases from the microalga Thalassiosira pseudonana. FEBS J., 272: 3,401-3,412.

Toyohara, H., Nakata, T., Touhata, K., Hashimoto, H., Kinoshita, K., Sakaguchi, M., Nishikima, M., Yagi, K., Wakamatsu, Y., and Ozato, K. 1996. Transgenic expression of L-guluno-(-lactone oxidase in medaka (Oryzias latipes), a teleost fish that lacks this enzyme necessary for L-ascorbic acid biosynthesis. Biochem. Biophys. Res. Commun. 223: 650--653.

Wan, H., He, J., Ju, B., Yan, T., Lam, T.J., and Gong, Z. 2002. Generation of two-color transgenic zebrafish using the green and red fluorescent protein reporter genes $g \mathrm{fp}$ and rfp. Mar. Biotechnol. 4: 146-154.

Wang, R., Zhang, P., Gong, Z., and Hew, C.L. 1995. Expression of the antifreeze protein gene in transgenic goldfish (Carassius auratus) and its implication in cold adaptation. Mol. Mar. Biol. Biotechnol. 4: 20--26.

Watanabe, T. and Vassallo-Agius, R. 2003. Broodstock nutrition research on marine finfish in Japan. Aquaculture. 227: 35--61.

Watanabe, T. 1993. Importance of docosa- hexaenoic acid in marine larval fish. J. World Aquacult. Soc. 24: 152--161.

Westerfield, M. 1995. The zebrafish book: a guide for the laboratory use of zebrafish (Danio rerio). University of Oregon Press, Eugene, Oregon. $93 \mathrm{pp}$.

Wu, F.C., Ting, Y.Y., and Chen, H.Y. 2003. Dietary docosahexaenoic acid is more optimal than eicosapentaenoic acid affecting the level of cellular defence responses of the juvenile grouper Epinephelus malabaricus. Fish and Shellfish Immunology. 14: 223-238.

Yazawa, R., Hirono, I., and Aoki, T. 2005. Characterization of promoter activities of four different Japanese flounder promoters in transgenic zebrafish. Marine Biotechnology, 7: 625--633.

Zhang, P., Hayat, M., Joyce, M., GonzalesVillasenor, C., Lin, C.M., Dunham R.A., Chen, T.T., and Powers, D.A. 1990. Gene transfer, expression and inheritance of pRSV-rainbow trout-GHcDNA in the carp, Cyprnius carpio (Linnaeus). Molec. Reprod. Dev. 25: 3--13.

Zhao, X., Zhang, P.J., and Wong, T.K. 1993. Application of Baekonization: a new approach to produce transgenic fish. Mol. Mar. Biol. Biotechnol. 2: 63--69.

Zheng, X., Tocher, D.R., Dickson, C.A., Bell, J.G., and Teale, A.J. 2005. Highly unsaturated fatty acid synthesis in vertebrates: new insight with the cloning and characterization of a delta 6 desaturase of Atlantic salmon. Lipids. 40: 13-24.

Zhu, Z., Li, G., He, L., and Chen, S. 1985. Novel gene transfer into the fertilized eggs of goldfish (Carassius auratus L. 1785). Z. Angew Ichthyol. 1: 31-34.

Zhu, Z., Xu, K., Li, G., Xie, Y., and He, L. 1986. Biological effects of human growth hormone gene injected into the fertilized eggs of loach Misgurnus anguillicaudatus (Cantor). Kexue Tongbao. 31: 988-990.

Zhu, Z. 1992. Generation of fast growing transgenic fish: methods and mechanisms. In: Transgenic Fish (C.L. Hew and G.L. Fletcher, (Eds.), World Scientific Publishing, Singapore. p. 92--119. 